Article

\title{
Biotransformation of Hydroxychalcones as a Method of Obtaining Novel and Unpredictable Products Using Whole Cells of Bacteria
}

\author{
Joanna Kozłowska ${ }^{1, *(\mathbb{D}, \text { Bartłomiej Potaniec }}{ }^{1,2}$ and Mirosław Anioł ${ }^{1}$ \\ 1 Department of Chemistry, Faculty of Biotechnology and Food Science, Wrocław University of Environmental \\ and Life Sciences, Norwida 25, 50-375 Wrocław, Poland; b.potaniec@gmail.com (B.P.); \\ miroslaw.aniol@upwr.edu.pl (M.A.) \\ 2 Łukasiewicz Research Network-PORT Polish Center for Technology Development, \\ Stabłowicka 147, 54-066 Wrocław, Poland \\ * Correspondence: joanna.kozlowska@upwr.edu.pl
}

Received: 27 September 2020; Accepted: 8 October 2020; Published: 12 October 2020

\begin{abstract}
The aim of our study was the evaluation of the biotransformation capacity of hydroxychalcones-2-hydroxy-4'-methylchalcone (1) and 4-hydroxy-4'-methylchalcone (4) using two strains of aerobic bacteria. The microbial reduction of the $\alpha, \beta$-unsaturated bond of 2-hydroxy- $4^{\prime}-$ methylchalcone (1) in Gordonia sp. DSM 44456 and Rhodococcus sp. DSM 364 cultures resulted in isolation the 2-hydroxy-4'-methyldihydrochalcone (2) as a main product with yields of up to $35 \%$. Additionally, both bacterial strains transformed compound 1 to the second, unexpected product of reduction and simultaneous hydroxylation at C-4 position-2,4-dihydroxy-4'-methyldihydrochalcone (3) (isolated yields $12.7-16.4 \%$ ). During biotransformation of 4-hydroxy-4'-methylchalcone (4) we observed the formation of three products: reduction of $\mathrm{C}=\mathrm{C}$ bond - 4-hydroxy-4'-methyldihydrochalcone (5), reduction of $\mathrm{C}=\mathrm{C}$ bond and carbonyl group-3-(4-hydroxyphenyl)-1-(4-methylphenyl)propan-1-ol (6) and also unpredictable 3-(4-hydroxyphenyl)-1,5-di-(4-methylphenyl)pentane-1,5-dione (7). As far as our knowledge is concerned, compounds 3, 6 and 7 have never been described in the scientific literature.
\end{abstract}

Keywords: biotransformation; biologically active compounds; chalcone; dihydrochalcone

\section{Introduction}

Chalcones are $\alpha, \beta$-unsaturated ketones belonging to polyphenolic compounds called flavonoids. Their chemical structure is characterized by an open flavanone skeleton consisting of two aromatic rings joined with a three-carbon linker containing a $\mathrm{C}=\mathrm{C}$ bond (Figure 1). Chalcones are bioactive compounds occurring in nature as plant secondary metabolites, which are a protective barrier against damage caused by microorganisms, insects or animals. Diversity of their structure results in a broad spectrum of activities e.g., anticancer [1], antibacterial [2], antifungal, antioxidant, anti-inflammatory and antimalarial [3-5]. Hydroxychalcones have attracted an unflagging interest in the scientific community due to an increased tendency to hydrogen bond between the - $\mathrm{OH}$ group and amino acids present in active sites of enzymes. Furthermore, non-polar effects among the aromatic rings A or B in chalcone and benzyl groups, of e.g., Tyr or Trp, enhance binding of hydroxychalcones with a peripheral anionic site of human acetylcholinesterase. These results showed potential of 2'-hydroxychalcone derivatives as inhibitors of Alzheimer's disease [6]. 


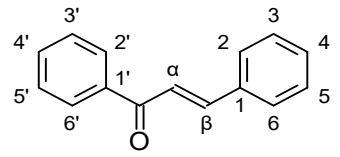

Chalcone

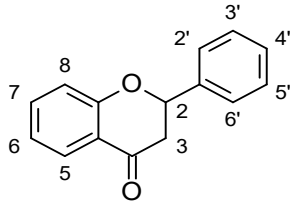

Flavanone

Figure 1. Structure of chalcone and flavanone.

Moreover, plant extracts are rich in chalcones with reduced double carbon-carbon bond known as dihydrochalcones. One of the most popular examples is phloretin $\left(2^{\prime}, 4^{\prime}, 6^{\prime}\right.$-trihydroxydihydrochalcone) and its glycosides forms, phlorizin (phloretin $2^{\prime}-\beta$-D-glucopyranoside) and phloretin $3^{\prime}, 5^{\prime}$-di-C-glucoside (Figure 2) occurring in apples, apple-derived products and kumquats [7]. Hydrogenation of the $\alpha, \beta$-unsaturated bond contributes to changing the flavor values of compounds. For instance, the presence of neohesperidin in citrus fruits is characterized by a bitter taste. However, neohesperidin dihydrochalcone is a non-cariogenic, intensive and hypocaloric sweetener permitted by the EU and the FDA as a food additive [8,9].<smiles>O=C(CCc1ccc(O)cc1)c1c(O)cc(O)cc1O</smiles>

Phloretin<smiles>O=C(CCc1ccc(O)cc1)c1c(O)c(C(OCCO)OCCO)c(O)c(C(O)CO)c1OCC(O)CO</smiles>

Phloretin 3,5-di-C-glucoside<smiles>O=C(CCc1ccc(O)cc1)c1c(O)cc(O)cc1OC1OCCC(O)CC(O)CO1</smiles>

Phlorizin<smiles>COc1ccc(C2CC(=O)c3c(O)cc(OC4OCC(O)C(O)C(O)C(O)C(O)C4O)cc3O2)cc1O</smiles>

Neohesperidin<smiles>O=c1c(-c2ccc(O)cc2)coc2cc(O)ccc12</smiles>

Daidzein<smiles>O=C(/C=C/c1ccc(O)cc1)c1ccc(O)cc1O</smiles>

Isoliquiritigenin<smiles>O=c1c(-c2ccc(O)cc2)coc2cc(O)cc(O)c12</smiles>

Genistein<smiles>O=C(/C=C/c1ccc(O)c(O)c1)c1ccc(O)cc1O</smiles>

Butein

Figure 2. Structures of flavonoids occurring in different plants.

Chemical hydrogenation of a double bond usually requires reagents containing transition metals, e.g., ruthenium or iridium complex $[10,11]$, which are relatively expensive. Biotransformation is an alternative method to obtain chalcone derivatives without harmful compounds. Biocatalysis is often described as a part of green chemistry because it is generally conducted under mild and safe conditions 
(room temperature and ambient pressure), avoids the use of toxic reagents and is usually performed in a water environment [12]. Furthermore, using whole cells of bacteria, yeast or fungi, has led to obtaining products in which classical synthesis would be troublesome or difficult to carry out.

Current knowledge about flavonoid biotransformation presents various possibilities of an enzymatic apparatus of microorganisms, which are able to catalyze different reactions e.g., hydroxylation, dehydroxylation, $\mathrm{O}$-methylation, $\mathrm{O}$-demethylation, glycosylation, deglycosylation, hydrogenation, dehydrogenation, $C$ ring cleavage, cyclization and reduction [13]. Microbial transformation leading to hydrogenation of the $\alpha, \beta$-unsaturated bond in chalcones is popular among bacteria, filamentous fungi and yeast whole cell cultures. So far, the best-known enzymes responsible for the reduction of the $\mathrm{C}=\mathrm{C}$ bond belongs to the Old Yellow Enzyme (OYE) family. Ene-reductases are flavin-dependent oxidoreductases that require $\mathrm{NAD}(\mathrm{P}) \mathrm{H}$ as a cofactor to their activity [14-16]. The OYE substrates include activated alkenes with an electron withdrawing groups (EWGs) such as aldehyde, ketone, nitro, carboxylic acid and other functional moieties [17]. The example of high bioconversion of 2'-hydroxychalcone is a microbial transformation in Yarrowia lipolytica and Saccharomyces cerevisiae cultures, which led to receiving the corresponding dihydrochalcone as a product [18]. It is worth mentioning that the same biocatalysis conducted by cyanobacteria Anabaena laxa lasted about five times longer with relatively low efficiency [19]. Interestingly, for the Gram-negative bacterium Stenotrophomonas maltophilia, 12-day biotransformation of 2'-hydroxy-3-methoxychalcone led to $2^{\prime}$-hydroxy-3-methoxydihydrochalcone with yield of $36.1 \%$ [20].

The capacity of microorganisms for hydroxylation is based on the activity of cytochrome P450 monooxygenases. The use of whole cell systems as biocatalysts allows to avoid the application of cofactors necessary for enzyme activity because of their natural presence [21]. The hydroxyl group's attachment to a flavonoid is widespread, especially among fungi, but has also been observed in plants and bacteria. Kostrzewa et al. described biotransformation of flavanone conducted in Aspergillus niger MB cultures which led to 6-hydroxyflavanone, while in Penicillium chermesinum 113 cultures, hydroxylation at C-4' position was observed [22]. Further, Roh et al. observed regioselective hydroxylation of soybean isoflavones-daidzein and genistein - by whole cells of Streptomyces avermitilis MA-4680 in the C-3' position [23]. According to biocatalysis by plants, microsomal enzyme preparations of Dahlia variabilis petals, converted the isoliquiritigenin to butein due to the incorporation of an $-\mathrm{OH}$ moiety in the C-3' position [24].

In this paper, we presented biotransformations of two hydroxychalcones-2-hydroxy$4^{\prime}$-methylchalcone (1) and 4-hydroxy-4'-methylchalcone (4). We selected two strains of aerobic bacteria-Gordonia sp. DSM 44456 and Rhodococcus sp. DSM 364-known for their ability to convert chalcones to dihydrochalcones and alcohol [25]. Moreover, as a result of action of these bacteria's whole-cell enzymatic apparatus, we isolated two novel products, which have not been described in the scientific reports.

\section{Results and Discussion}

The result of classical base-catalyzed aldol condensation performed according to the method described by Amir et al. we received 2-hydroxy-4'-methylchalcone (1) and 4-hydroxy-4'methylchalcone (4) with yield $33.3 \%$ and $43.7 \%$, respectively [26]. Both synthesized derivatives were used as substrates for biotransformation. So far, literature reported the ability of Corynebacterium equi to transform a $4^{\prime}$-methylchalcone into $4^{\prime}$-methyldihydrochalcone after $72 \mathrm{~h} \mathrm{[27].} \mathrm{Our} \mathrm{previous}$ investigations proved the capability of the enzymatic apparatus of Gordonia sp. DSM 44456 and Rhodococcus sp. DSM 364 to catalyzed the reduction of the $\alpha, \beta$-unsaturated bond in chalcones in a relatively short time. Moreover, extending the time of bioconversion led to obtaining a second metabolite—product of reduction carbonyl group—alcohol [25].

Biotransformations conducted on a small scale have shown that Gordonia sp. DSM 44456 and Rhodococcus sp. DSM 364 are able to complete the conversion of 2-hydroxy-4'-methylchalcone (1) after $24 \mathrm{~h}$. However, extending the biotransformation to $72 \mathrm{~h}$ resulted in the creation of additional 
metabolites. In the case of 4-hydroxy-4'-methylchalcone (4) biocatalysis, three products were detected in both bacterial cultures after $24 \mathrm{~h}$.

\subsection{Biotransformation of 2-Hydroxy-4'-Methylchalcone (1)}

As a result of the biotransformation of 2-hydroxy-4'-methylchalcone (1) carried out on a preparative scale using whole cells of Gordonia sp. DSM 44456 and Rhodococcus sp. DSM 364, 2-hydroxy-4'-methyldihydrochalcone (2) was isolated. This product of $\mathrm{C}=\mathrm{C}$ bond hydrogenation (compound 2) was obtained by Shang et al. in chemical synthesis using tosylhydrazine [28]. Analysis of the ${ }^{1} \mathrm{H}-\mathrm{NMR}$ spectrum confirmed the structure of the final dihydrochalcone (2). Characteristics of chalcones signals from $\mathrm{H}-\alpha$ at $7.88 \mathrm{ppm}$ and $\mathrm{H}-\beta$ at $8.18 \mathrm{ppm}$ with the same coupling constant $(J=15.8 \mathrm{~Hz})$ were observed on a proton nuclear magnetic resonance spectrum of 2-hydroxy-4'-methylchalcone (1). In the case of 2-hydroxy-4'-methyldihydrochalcone (2), the downshift multiplets from two saturated protons $\mathrm{H}-\alpha$ and $\mathrm{H}-\beta$ were detected at 3.45-3.41 ppm and 3.05-3.01 ppm, respectively. Additionally, a singlet at $189.80 \mathrm{ppm}$ and $201.83 \mathrm{ppm}$ in the ${ }^{13} \mathrm{C}-\mathrm{NMR}$ spectra confirmed the presence of carbonyl group in substrate (1) and biotransformation product (2), respectively. It is clear that downshifted signals from $C-\alpha$ and $C-\beta$ at $122.46 \mathrm{ppm}$ and $140.05 \mathrm{ppm}$ to $40.48 \mathrm{ppm}$ and $23.50 \mathrm{ppm}$ indicated the bioreduction of $\mathrm{C}=\mathrm{C}$ bond in chalcone (1). High-performance liquid chromatography (HPLC) and thin-layer chromatography (TLC) analyses showed that extending the time of biotransformation of compound 1 was carried out to another metabolite. Initially, we expected product of reduction of carbonyl group-alcohol. Surprisingly, after $72 \mathrm{~h}$ of microbial transformation, we isolated 2,4-dihydroxy-4'-methyldihydrochalcone (3) (Scheme 1). In the literature, Rhodococcus species are well known for their broad potential to degrade environmental pollutants and naturally occurring steroids. Well-known 3-ketosteroid $9 \alpha$-hydroxylase (KSH) present in Rhodococcus erythropolis strain SQ1 is a key enzyme responsible for the microbial catabolic pathway of 4-androstene-3,17-dione (AD) to its $9 \alpha$-hydroxy derivative [29]. KSH activity was also observed in various actinobacterial genera, e.g., Mycobacterium, Nocardia and Arthrobacter [30]. Li et al. described hydroxylation of D-limonene to enantiomerically pure (+)-trans-carveol in Rhodococcus opacus PWD4 culture [21]. In the case of flavonoid compounds, Kostrzewa et al. described the ability of Aspergillus niger MB (UV mutant) and Penicillium chermesinum 113 to introduce an $-\mathrm{OH}$ group in the $\mathrm{C}-6$ and $\mathrm{C}-4^{\prime}$ position in flavanone. However, dihydrochalcones received by authors were results of cleavage flavonoid ring C [22]. To our knowledge, no prior work has been done on the hydroxylation of chalcones using the Rhodococcus sp. strain. In our study, the structure of product 3 was confirmed by ${ }^{1} \mathrm{H}$ and ${ }^{13} \mathrm{C}-\mathrm{NMR}$ spectra. Similar to compound 2, two multiplets at 3.42-3.38 ppm and 2.98-2.94 ppm from two saturated protons $\mathrm{H}-\alpha$ and $\mathrm{H}-\beta$ were observed. Furthermore, a singlet at $4.77 \mathrm{ppm}$ attributed to hydroxyl group at the C-4 was indicated. The incorporation of an $-\mathrm{OH}$ moiety to the $\mathrm{C}-4$ position described the upshifted signal from $132.48 \mathrm{ppm}$ to $149.48 \mathrm{ppm}$ in the ${ }^{13} \mathrm{C}-\mathrm{NMR}$ spectrum.

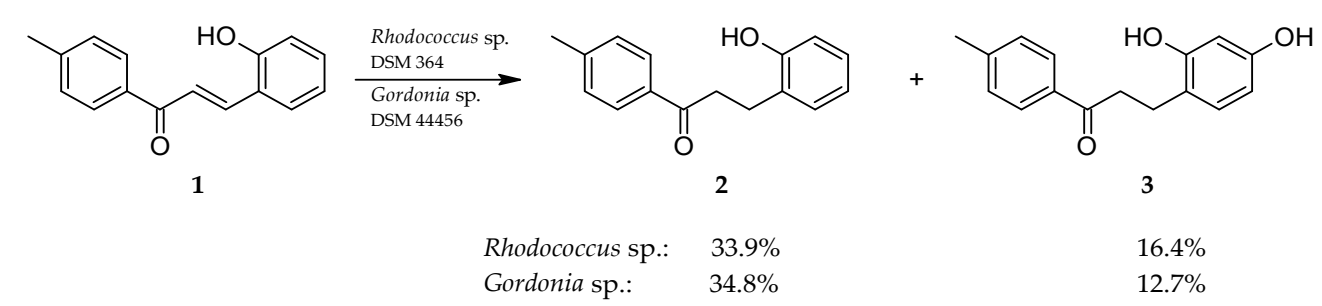

Scheme 1. Biotransformation of 2-hydroxy $-4^{\prime}$-methylchalcone (1) with isolated yields.

\subsection{Biotransformation of 4-Hydroxy-4'-Methylchalcone (4)}

Biotransformation on a preparative scale of 4-hydroxy-4'-methylchalcone (4) in Gordonia sp. DSM 44456 and Rhodococcus sp. DSM 364 culture allowed us to obtain three products after $24 \mathrm{~h}$ (Scheme 2). Bioconversion of chalcone 4 in Gordonia sp. DSM 44456 culture led to $38.4 \mathrm{mg}$ ( $42.3 \%$ yield) 
of 4-hydroxy-4'-methyldihydrochalcone (5). Transformation of 4-hydroxy-4'-methylchalcone (4) performed in Rhodococcus sp. DSM 364 culture gave us $49.1 \mathrm{mg}$ ( $54.1 \%$ yield) of metabolite 5 after the same time of incubation. Analysis of the ${ }^{1} \mathrm{H}-\mathrm{NMR}$ spectrum confirmed the presence of multiplets characteristic of dihydrochalcones from two protons $\mathrm{H}-\alpha$ and two protons $\mathrm{H}-\beta$ at 3.27-3.21 ppm and 3.02-2.96 ppm. Further, downshifted signals in the ${ }^{13} \mathrm{C}-\mathrm{NMR}$ spectrum at $40.75 \mathrm{ppm}$ and $29.57 \mathrm{ppm}$ from $C-\alpha$ and $C-\beta$ were observed, respectively. Beside compound 5 , from the same biotransformation mixture, we isolated a second metabolite-3-(4-hydroxyphenyl)-1-(4-methylphenyl)propan-1-ol (6) in amount $5.8 \mathrm{mg}$ (6.3\% yield) in Gordonia sp. DSM 44456 culture and $8.3 \mathrm{mg}$ (9.1\% yield) in Rhodococcus sp. DSM 364 culture. Downshifted multiplets in the ${ }^{1} \mathrm{H}-\mathrm{NMR}$ in the spectral range of $2.69-1.95 \mathrm{ppm}$ came from saturated $\mathrm{H}-\alpha$ and $\mathrm{H}-\beta$. Furthermore, characteristic doublets at $4.64 \mathrm{ppm}(J=7.8,5.5 \mathrm{~Hz})$ were attributed to a proton from a reduced $\mathrm{C}=\mathrm{O}$ bond. Additionally, a broad signal at $5.00 \mathrm{ppm}$ indicated a proton from hydroxyl moiety at $\mathrm{C}-4$ and at $1.66 \mathrm{ppm}$ from alcohol-OH group. Downshifted signals in the ${ }^{13} \mathrm{C}$-NMR spectrum from $189.33 \mathrm{ppm}$ to $73.93 \mathrm{ppm}$ confirm the absence of a carbonyl group in compound 6. Downshifted signals from $C-\alpha$ and $C-\beta$ at $40.65 \mathrm{ppm}$ and at $31.30 \mathrm{ppm}$, respectively, proved that the isolated product contains a saturated $\alpha, \beta$ bond. Moreover, we determined the enantiomeric excess (ee) of alcohol 6 using chiral HPLC analysis. We performed a reaction of 4-hydroxy-4'-methyldihydrochalcone (5) with lithium aluminum hydride to obtain racemate of compound 6, which was compared with the alcohol obtained by biotransformation. The chiral HPLC analysis of product 6 showed $e e=78 \%$. The optical rotation of 3-(4-hydroxyphenyl)-1-(4-methylphenyl)propan-1-ol (6) was $[\alpha]_{D}^{20}=-11.321$ $\left(c=0.7 ; \mathrm{CHCl}_{3}\right)$.

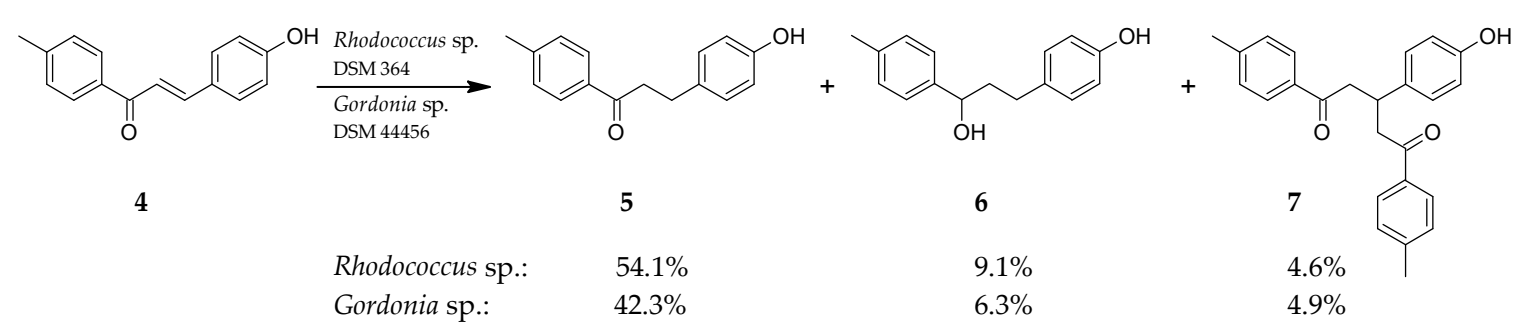

Scheme 2. Biotransformation of 4-hydroxy-4'-methylchalcone (4) with isolated yields.

Our research team's previous investigations proved that compounds 5 and $\mathbf{6}$ were anticipated products of the enzymatic apparatus of Gordonia sp. DSM 44456 and Rhodococcus sp. DSM 364 species [25]. Surprisingly, we isolated a novel product-3-(4-hydroxyphenyl)1,5-di-(4-methylphenyl)pentane-1,5-dione (7). Current literature describes the Michael reaction as an efficient method of formation carbon-carbon bond leading to 1,5-diketones. Nowadays, there are many possibilities to obtain 1,3,5-triarylpentan-1,5-dione derivatives from chalcones and enolates using e.g., trimethyl orthoformate, triflic acid and carbon tetrachloride as a solvent [31], various barium alkoxides [32], sodium sulfide [33] or using microwave irradiation [34], which are not as environmentally friendly as biotransformations. To our knowledge, there are no prior studies to obtain 1,3,5-triarylpentan-1,5-diones as a result of microbial transformation, without such harmful and toxic reagents. Analysis of ${ }^{1} \mathrm{H}-\mathrm{NMR}$ showed characteristics for this structures; a doublet of doublets in both cases from two protons-one from $\mathrm{H}-2^{\prime \prime \prime}$ and one from $\mathrm{H}-4^{\prime \prime \prime}$ - at $3.45 \mathrm{ppm}(J=16.2,6.9 \mathrm{~Hz})$ and at $3.23 \mathrm{ppm}(\mathrm{dd}, J=16.2,7.3 \mathrm{~Hz})$, respectively. Moreover, pentet from $\mathrm{H}-3^{\prime \prime \prime}$ at $3.96 \mathrm{ppm}(J=7.1 \mathrm{~Hz})$ was observed. Also downshifted signals on ${ }^{13} \mathrm{C}-\mathrm{NMR}$ spectrum at $45.40 \mathrm{ppm}$ derived from two carbons C-2'" , C- $4^{\prime \prime \prime}$ and at $37.19 \mathrm{ppm}$ derived from C- $3^{\prime \prime \prime}$ confirm structure of isolated product. The high-resolution mass spectrometry analysis provided additional evidence of the unexpected product being obtained. The biotransformation product showed on HR ESI-MS spectrum the molecular ion peak $\left[\mathrm{C}_{25} \mathrm{H}_{24} \mathrm{O}_{3}+\mathrm{H}\right]^{+}$at $\mathrm{m} / z 373.1800$ and the calculated value for the same formula was 373.1798 , which confirms the mass of the analyzed compound. 
Summarizing, both biocatalysts—Gordonia sp. and Rhodococcus sp.-are able to hydrogenate the $\alpha, \beta$-unsaturated bond in the presented hydroxychalcones $\mathbf{1}$ and $\mathbf{4}$ to obtain dihydrochalcones $\mathbf{2}$ and $\mathbf{5}$ as the main products, respectively. Additionally, both strains hydroxylated 2-hydroxy-4'-methylchalcone (1) at C-4 position with isolated yields up to $16.4 \%$. Literature reports the ability of Rhodococcus species to attach hydroxyl moiety to an aromatic ring in the ortho position to methyl and para position to methoxy groups [35]. The possibility of aromatic hydroxylation is connected with the well-known cytochrome P450 RhF (CYP116B2) from Rhodococcus sp. NCIMB 9784 [36]. Notwithstanding, in our previous studies on the transformation of different 4'-methylchalcones using whole cells of Rhodococcus sp. DSM 364, we observed neither products of hydroxylation, nor 1,3,5-triarylpentan-1,5-dione derivatives [25].

\section{Materials and Methods}

\subsection{Chemicals}

Reagents for chemical synthesis and organic solvents (analytical and HPLC grade) were purchased from Sigma-Aldrich (St. Louis, MO, USA), Merck (Darmstadt, Germany) or Chempur (Piekary Śląskie, Poland).

\subsection{Synthesis of 2-Hydroxy-4'-Methylchalcone (1) and 4-Hydroxy-4'-Methylchalcone (4)}

Chalcones 2-hydroxy-4'-methylchalcone (1) and 4-hydroxy-4'-methylchalcone (4) used as substrates in biotransformation were synthesized in classical Claisen-Schmidt condensation according to the protocol described by Amir et al. [26].

2-hydroxy-4'-methylchalcone (1) (591.4 mg, yield 33.3\%) yellow powder, m.p. $148-150{ }^{\circ} \mathrm{C}$, lit. $150{ }^{\circ} \mathrm{C}[37] .{ }^{1} \mathrm{H}$ NMR $\left(600 \mathrm{MHz}\right.$, Acetone- $\left.d_{6}\right) \delta(\mathrm{ppm}): 9.17(\mathrm{~s}, 1 \mathrm{H}, 2-\mathrm{O} \underline{\mathrm{H}}), 8.18(\mathrm{~d}, J=15.8 \mathrm{~Hz}, 1 \mathrm{H}$, H- $\beta$ ), 8.05-7.99 (m, AA'BB' $\left.2 \mathrm{H}, \mathrm{H}-2^{\prime}, \mathrm{H}^{\prime} 6^{\prime}\right), 7.88(\mathrm{~d}, J=15.8 \mathrm{~Hz}, 1 \mathrm{H}, \mathrm{H}-\alpha), 7.81(\mathrm{dd}, J=7.8,1.6 \mathrm{~Hz}, 1 \mathrm{H}$, H-6), 7.38-7.33 (m, AA'BB', 2H, H-3', H-5'), 7.28 (ddd, $J=8.2,7.2,1.6 \mathrm{~Hz}, 1 \mathrm{H}, \mathrm{H}-4), 7.00$ (dd, $J=8.2$, $1.0 \mathrm{~Hz}, 1 \mathrm{H}, \mathrm{H}-3), 6.95-6.90$ (m, 1H, H-5), 2.41 (s, 3H, $\left.-\mathrm{CH}_{3}\right) ;{ }^{13} \mathrm{C}$ NMR (150 MHz, Acetone- $\left.d_{6}\right) \delta(\mathrm{ppm})$ : $189.80(\underline{C}=\mathrm{O}), 157.82(\mathrm{C}-2), 144.10\left(\mathrm{C}-4^{\prime}\right), 140.05(\mathrm{C}-\beta), \overline{13} 6.90\left(\mathrm{C}-1^{\prime}\right), 132.48(\mathrm{C}-4), 130.09\left(\mathrm{C}-3^{\prime}, \mathrm{C}^{\prime} 5^{\prime}\right)$, 129.73 (C-6), 129.32 (C-2', C-6'), 123.02 (C-1), 122.46 (C- $\alpha), 120.85$ (C-5), 117.07 (C-3), $21.54\left(-\mathrm{CH}_{3}\right)$.

4-hydroxy-4' -methylchalcone (4) (775.2 mg, yield 43.7\%) yellow powder, m.p. $159-161{ }^{\circ} \mathrm{C}$, lit. 156-158 ${ }^{\circ} \mathrm{C}$ [38]. ${ }^{1} \mathrm{H}$ NMR $\left(600 \mathrm{MHz}\right.$, Acetone- $\left.d_{6}\right) \delta(\mathrm{ppm}): 8.97(\mathrm{~s}, 1 \mathrm{H}, 4-\mathrm{OH}), 8.05-8.00\left(\mathrm{~m}, \mathrm{AA}^{\prime} \mathrm{BB}^{\prime}\right.$,

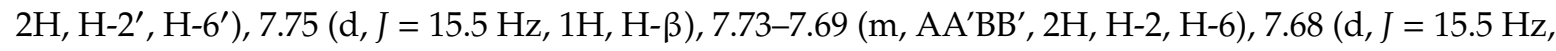

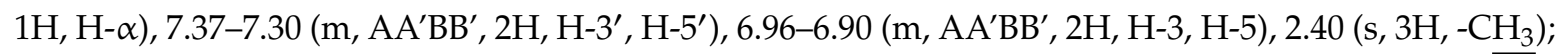
${ }^{13} \mathrm{C}$ NMR $\left(150 \mathrm{MHz}\right.$, Acetone- $\left.d_{6}\right) \delta 189.33(\underline{\mathrm{C}}=\mathrm{O}), 160.70(\mathrm{C}-4), 144.75(\mathrm{C}-\beta), 144.02\left(\mathrm{C}-4^{\prime}\right), 136.89\left(\mathrm{C}-1^{\prime}\right)$, 131.46 (C-2, C-6), 130.04 (C-3', C-5'), 129.28 (C-2', C-6' $), 127.69$ (C-1), 119.69 (C- $\alpha), 116.71$ (C-3, C-5), $21.53\left(-\mathrm{CH}_{3}\right)$.

Spectroscopic data of both substances (1) and (4) were identical to this reported in the literature (Supplementary Materials, Figures S1, S2 and S7, S8).

\subsection{Biotransformations}

Biotransformations were performed according to the method described by our research team in previous paper [25]. Briefly, we used two bacteria-Gordonia sp. DSM 44456 and Rhodococcus sp. DSM 364. Biotransformations were performed in small and preparative scale. Details information are described below.

\subsubsection{Biotransformation in Small Scale}

Biotransformation in small scale was performed in $100 \mathrm{~mL}$ Erlenmeyer flasks containing $25 \mathrm{~mL}$ of culture medium. Sterile culture medium was inoculated using $0.1 \mathrm{~mL}$ of bacteria suspension and then incubated at $28^{\circ} \mathrm{C}$ on rotary shaker. After $48 \mathrm{~h}, 1 \mathrm{mg}$ of substrate (compound 1 or 4 ) dissolved in $0.5 \mathrm{~mL}$ acetone was added to the culture and shaking of biotransformation mixtures was continued at $28^{\circ} \mathrm{C}$. Progress of bioconversion was monitored by the thin layer chromatography (TLC) and the liquid 
high-performance chromatography (HPLC). Stability of substrates was verified in sterile medium at the same incubation conditions as the biotransformation mixture.

\subsubsection{Biotransformation in Preparative Scale}

To determine products observed in screening scale, preparative biotransformation using 2000 $\mathrm{mL}$ Erlenmeyer flasks were performed. Each flask contained $300 \mathrm{~mL}$ of sterile culture medium, which was inoculated with $1 \mathrm{~mL}$ of bacteria suspension and maintained at $28^{\circ} \mathrm{C}$ on rotary shaker. After $48 \mathrm{~h}, 30 \mathrm{mg}$ of substrate (compound 1 or 4) dissolved in $1 \mathrm{~mL}$ acetone was added to the grown culture. Incubation was continued under the same conditions as in small scale. After the complete substrate conversion, biotransformation mixture was extracted with ethyl acetate $(3 \times 100 \mathrm{~mL})$. Collected organic fractions were dried over anhydrous sodium sulphate and evaporated in a vacuum evaporator. The biotransformation extracts were purified on column chromatography filled with silica gel (Kieselgel 60, 0.040-0.063 mm, 230-400 mesh, Merck, Darmstadt, Germany) using mixture of hexane:ethyl acetate 5:1 (v/v) (compound 4) or 5:2 (v/v) (compound 1) as eluent. Purity of isolated products was verified by HPLC. Structures of obtained compounds were determined using ${ }^{1} \mathrm{H}$ and ${ }^{13} \mathrm{C}$ NMR and HR ESI-MS.

\subsection{Analytical Methods}

Thin layer chromatography (TLC) on silica gel-coated aluminum plates with fluorescent indicator (DC-Alufolien, Kieselgel $60 \mathrm{~F}_{254}$; Merck, Darmstadt, Germany) was used to estimation progress of biotransformation. Compounds were visualized by spraying the plates with a solution of $1 \% \mathrm{Ce}\left(\mathrm{SO}_{4}\right)_{2}$

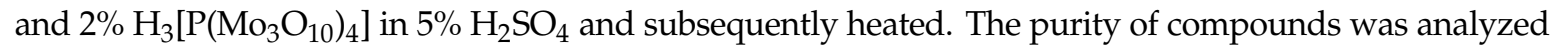
using HPLC apparatus Waters 2690 (Milford, MA, USA) with Photodiode Array Detector Waters 996. The samples were dissolved in methanol and injected on a reverse-phase C-18 column with pre-column as integral part (Phenomenex, Torrance, CA, United States, Kinetex 5u XB-C18 100A, $250 \mathrm{~mm} \times 4.6 \mathrm{~mm}$ ), which was thermostated at $28^{\circ} \mathrm{C}$, and analysed samples were kept at $12^{\circ} \mathrm{C}$. The mobile phase consisted of two eluents $\mathrm{A}\left(1 \% \mathrm{HCOOH}\right.$ in $\left.\mathrm{H}_{2} \mathrm{O}\right)$ and $\mathrm{B}(1 \% \mathrm{HCOOH}$ in $\mathrm{MeCN})$. Elution gradient was: $0-1 \mathrm{~min}$ : $55 \%$ of eluent $A, 1-8$ min: $55-10 \%$ of eluent $A, 8-11 \mathrm{~min}: 10 \%$ of eluent $A, 11-12$ min: $10-55 \%$ of eluent $A$ and $12-15 \mathrm{~min}$ : $55 \%$ of eluent $A$ with flow rate of $1.5 \mathrm{~mL} / \mathrm{min}$. The retention time (RT, min) of synthesized chalcones and biotransformation products: 2-hydroxy-4'-methylchalcone (1)-6.020 min; 2-hydroxy-4'-methyldihydrochalcone (2) - $6.224 \mathrm{~min} ; 2,4$-dihydroxy-4' -methyldihydrochalcone (3) - 3.740 min; 4-hydroxy-4'-methylchalcone (4) - $5.449 \mathrm{~min}$; 4-hydroxy-4'-methyldihydrochalcone (5)—5.481 min; 3-(4-hydroxyphenyl)-1-(4-methylphenyl)propan-1-ol (6)-4.219 $\mathrm{min}$; 3-(4-hydroxyphenyl) -1,5-di-(4-methylphenyl)pentane-1,5-dione (7)-7.331 min.

To determine the enantiomeric excess the chiral HPLC analysis was performed. We used Chiralpak AD-H column (Daicel Chemical Industries, LTD, Arai Plant, Japan, $0.46 \mathrm{~cm} \times 25 \mathrm{~cm}$ ) equipped with a Guard Cartridge Holder (Daicel Chemical Industries, LTD, Arai Plant, Japan, $10 \mathrm{~mm} \times 4 \mathrm{~mm}$ ), which were kept at $25{ }^{\circ} \mathrm{C}$. The analysis was conducted in isocratic elution and the mobile phase consisted of $90 \%$ of hexane and $10 \%$ of trifluoroacetic acid $(0.01 \%)$, isopropyl alcohol $(65 \%)$ and methanol (35\%). The time of analysis was $25 \mathrm{~min}$ and the flow rate of $1 \mathrm{~mL} / \mathrm{min}$.

Nuclear magnetic resonance (NMR) analysis was used to determine structures of obtained compounds. ${ }^{1} \mathrm{H}-\mathrm{NMR},{ }^{13} \mathrm{C}-\mathrm{NMR}$ and correlation spectra (COSY, HSQC) were recorded on a Bruker Avance ${ }^{\mathrm{TM}} 600 \mathrm{MHz}$ spectrometer (Bruker, Billerica, MA, USA) with acetone- $d_{6}$ and chloroform- $d$ as solvent.

Positive and negative-ion HR ESI-MS spectra were measured on a Bruker ESI-Q-TOF Maxis Impact Mass Spectrometer (Bruker, Billerica, MA, USA). The direct infusion of ESI-MS parameters: the mass spectrometer was operated in positive $(2,3,5,7)$ and negative (6) ion mode with the potential of $3.5 \mathrm{kV}$ between the spray needle and the orifice, nebulizer pressure of $0.4 \mathrm{bar}$, and a drying gas flow rate of $3.0 \mathrm{~L} / \mathrm{min}$ at $200^{\circ} \mathrm{C}$. The sample flow rate was set at $3.0 \mu \mathrm{L} / \mathrm{min}$. Ionization mass spectra were collected at the ranges $m / z$ 50-1250. 
Optical rotation was measured on Jasco P-2000 automatic polarimeter (ABL\&E-JASCO, Kraków, Poland) and the solution was prepared in chloroform. The concentration was expressed in $\mathrm{g} / 100 \mathrm{~mL}$.

To determine the melting points (uncorrected) a Boetius apparatus was used.

\subsection{Isolated Biotransformations Products}

2-hydroxy-4'-methyldihydrochalcone (2) (Gordonia sp. DSM 44456, $31.6 \mathrm{mg}$, yield $34.8 \%$, Rhodococcus sp. DSM 364, $30.8 \mathrm{mg}$, yield 33.9\%) white powder, m.p. $127-129{ }^{\circ} \mathrm{C} .{ }^{1} \mathrm{H}$ NMR $(600 \mathrm{MHz}$, Chloroform- $d$ ) $\delta$ (ppm): $8.12(\mathrm{~s}, 1 \mathrm{H}, 2-\mathrm{OH}), 7.90-7.86\left(\mathrm{~m}, \mathrm{AA}^{\prime} \mathrm{BB}^{\prime}, 2 \mathrm{H}, \mathrm{H}-2^{\prime}, \mathrm{H}-6^{\prime}\right), 7.24(\mathrm{~d}, J=8.0 \mathrm{~Hz}, 2 \mathrm{H}$, H-3' ${ }^{\prime}$ H-5'), 7.14-7.08 (m, 2H, H-4, H-6), 6.94-6.89 (m, 1H, H-3), 6.88-6.82 (m, 1H, H-5), 3.45-3.41 (m, 2H, $2 \mathrm{H}-\alpha), 3.05-3.01(\mathrm{~m}, 2 \mathrm{H}, 2 \mathrm{H}-\beta), 2.40\left(\mathrm{~s}, 3 \mathrm{H},-\mathrm{CH}_{3}\right) ;{ }^{13} \mathrm{C}$ NMR $(150 \mathrm{MHz}$, Chloroform- $d$ ) $\delta$ (ppm): $201.83(\underline{\mathrm{C}}=\mathrm{O}), 154.72(\mathrm{C}-2), 144.92\left(\mathrm{C}-4^{\prime}\right), 133.71 \overline{\left(\mathrm{C}-1^{\prime}\right)}, 130.71(\mathrm{C}-6), 129.47\left(\mathrm{C}-3^{\prime}, \mathrm{C}-5^{\prime}\right), 128.60\left(\mathrm{C}-2^{\prime}\right.$, C-6'), 128.08 (C-4), 128.02 (C-1), 120.75 (C-5), 117.68 (C-3), 40.48 (C- $\alpha), 23.50(\mathrm{C}-\beta), 21.85\left(-\mathrm{CH}_{3}\right)$; HR ESI-MS $m / z$ calculated for $\mathrm{C}_{16} \mathrm{H}_{16} \mathrm{O}_{2}[\mathrm{M}+\mathrm{H}]^{+} 241.1223$, found $[\mathrm{M}+\mathrm{H}]^{+} 241.1223$.

2,4-dihydroxy-4'-methyldihydrochalcone (3) (Gordonia sp. DSM 44456, $12.3 \mathrm{mg}$, yield 12.7\%, Rhodococcus sp. DSM 364, $15.9 \mathrm{mg}$, yield $16.4 \%)$ creamy powder, m.p. $74-76{ }^{\circ} \mathrm{C} .{ }^{1} \mathrm{H}$ NMR $(600 \mathrm{MHz}$, Chloroform- $d$ ) $\delta$ (ppm): 7.89-7.83 (m, $\left.\mathrm{AA}^{\prime} \mathrm{BB}^{\prime}, 2 \mathrm{H}, \mathrm{H}-2^{\prime}, \mathrm{H}-6^{\prime}\right), 7.75(\mathrm{~s}, 1 \mathrm{H}, 2-\mathrm{O} \underline{\mathrm{H}}), 7.26-7.21$ (m, $\mathrm{AA}^{\prime} \mathrm{BB}^{\prime}$, 2H, H-3', $\left.\mathrm{H}-5^{\prime}\right), 6.79$ (d, J = 8.5 Hz, 1H, H-6), 6.62 (d, J = 3.0 Hz, 1H, H-3), 6.58 (dd, J = 8.5, $3.0 \mathrm{~Hz}, 1 \mathrm{H}$, $\mathrm{H}-5), 4.77(\mathrm{~s}, 1 \mathrm{H}, 4-\mathrm{OH}), 3.42-3.38(\mathrm{~m}, 2 \mathrm{H}, 2 \mathrm{H}-\alpha), 2.98-2.94(\mathrm{~m}, 2 \mathrm{H}, 2 \mathrm{H}-\beta), 2.40\left(\mathrm{~s}, 3 \mathrm{H},-\mathrm{CH}_{3}\right) ;{ }^{13} \mathrm{C} \mathrm{NMR}$ $\left(150 \mathrm{MHz}\right.$, Chloroform- $d$ ) $\delta$ (ppm): $201.68(\underline{\mathrm{C}}=\mathrm{O}), 149.48(\mathrm{C}-4), 148.36(\mathrm{C}-2), 144.97\left(\mathrm{C}-4^{\prime}\right), 133.69\left(\mathrm{C}-1^{\prime}\right)$, 129.49 (C-3', C-5'), 129.24 (C-1), 128.60 (C-2' C-6 $\left.^{\prime}\right), 118.54$ (C-6), 116.92 (C-3), 114.76 (C-5), 40.37 (C- $\left.\alpha\right)$, $23.60(\mathrm{C}-\beta), 21.85\left(-\mathrm{CH}_{3}\right)$; HR ESI-MS $m / z$ calculated for $\mathrm{C}_{16} \mathrm{H}_{16} \mathrm{O}_{3}[\mathrm{M}+\mathrm{H}]^{+} 257.1172$, found $[\mathrm{M}+\mathrm{H}]^{+}$ 257.1173.

4-hydroxy-4'-methyldihydrochalcone (5) (Gordonia sp. DSM 44456, $38.4 \mathrm{mg}$, yield 42.3\%, Rhodococcus sp. DSM 364, $49.1 \mathrm{mg}$, yield 54.1\%) white powder, mp. 84-86 ${ }^{\circ} \mathrm{C} .{ }^{1} \mathrm{H} \mathrm{NMR}(600 \mathrm{MHz}$, Chloroform- $d$ ) $\delta$ (ppm): 7.88-7.83 (m, $\left.\mathrm{AA}^{\prime} \mathrm{BB}^{\prime}, 2 \mathrm{H}, \mathrm{H}-2^{\prime}, \mathrm{H}-6^{\prime}\right), 7.26-7.23$ (m, $\left.\mathrm{AA}^{\prime} \mathrm{BB}^{\prime}, 2 \mathrm{H}, \mathrm{H}-3^{\prime}, \mathrm{H}-5^{\prime}\right)$,

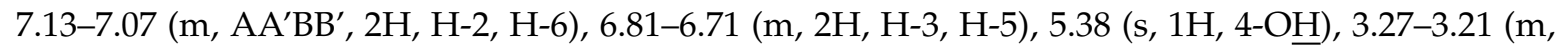
$2 \mathrm{H}, 2 \mathrm{H}-\alpha), 3.02-2.96(\mathrm{~m}, 2 \mathrm{H}, 2 \mathrm{H}-\beta), 2.41\left(\mathrm{~s}, 3 \mathrm{H},-\mathrm{CH}_{3}\right) ;{ }^{13} \mathrm{C}$ NMR $(150 \mathrm{MHz}, \mathrm{Chloroform}-d) \delta(\mathrm{ppm})$ : $199.75(\underline{\mathrm{C}}=\mathrm{O}), 154.15(\mathrm{C}-4), 144.10\left(\mathrm{C}-4^{\prime}\right), 134.44\left(\mathrm{C}-1^{\prime}\right), 133.38$ (C-1), $129.63(\mathrm{C}-2, \mathrm{C}-6), 129.43\left(\mathrm{C}-3^{\prime}, \mathrm{C}^{\prime} 5^{\prime}\right)$, $128.36\left(\mathrm{C}-2^{\prime}, \mathrm{C}-6^{\prime}\right), 115.49(\mathrm{C}-3, \mathrm{C}-5), 40.75(\mathrm{C}-\alpha), 29.57(\mathrm{C}-\beta), 21.77\left(-\mathrm{CH}_{3}\right)$; HR ESI-MS m/z calculated for $\mathrm{C}_{16} \mathrm{H}_{16} \mathrm{O}_{2}[\mathrm{M}+\mathrm{H}]^{+}$241.1223, found $[\mathrm{M}+\mathrm{H}]^{+} 241.1225$.

3-(4-hydroxyphenyl)-1-(4-methylphenyl)propan-1-ol (6) (Gordonia sp. DSM 44456, $5.8 \mathrm{mg}$, yield $6.3 \%$, Rhodococcus sp. DSM 364, $8.3 \mathrm{mg}$, yield 9.1\%) light yellow oil, $[\alpha]_{D}^{20}=-11.321(c=0.7$; $\left.\mathrm{CHCl}_{3}\right) ; e e=78 \% .{ }^{1} \mathrm{H}$ NMR $(600 \mathrm{MHz}$, Chloroform- $d) \delta(\mathrm{ppm}): 7.25-7.22\left(\mathrm{~m}, \mathrm{AA}^{\prime} \mathrm{BB}^{\prime}, 2 \mathrm{H}, \mathrm{H}-2^{\prime}\right.$, H-6'), 7.16 (d, J = 7.8 Hz, 2H, H-3', H-5'), 7.06-7.02 (m, AA'BB', 2H, H-2, H-6), 6.77-6.70 (m, AA'BB', 2H, H-3, H-5), 5.00 (br s, $1 \mathrm{H}, 4-\mathrm{OH}), 4.64$ (dd, $J=7.8,5.5 \mathrm{~Hz}, 1 \mathrm{H},-\underline{\mathrm{H}}-\mathrm{OH}), 2.69-2.61(\mathrm{~m}, 1 \mathrm{H}, \mathrm{H}-\beta)$, 2.62-2.54 (m, 1H, H- $\beta$ ), 2.35 (s, 3H, $\left.-\mathrm{CH}_{3}\right), 2.14-2.05$ (m, 1H, H- $\left.\alpha\right), 2.00-1.95(\mathrm{~m}, 1 \mathrm{H}, \mathrm{H}-\alpha), 1.66$ (br s, $1 \mathrm{H},-\mathrm{CH}-\mathrm{OH}) ;{ }^{13} \mathrm{C}$ NMR $(150 \mathrm{MHz}, \mathrm{Chloroform}-d) \delta(\mathrm{ppm}): 153.81$ (C-4), 141.59 (C-1'), 137.51 (C-4'), 134.00 (C-1), 129.63 (C-2, C-6), 129.34 (C-3', C-5'), 126.05 (C-2', C-6'), 115.34 (C-3, C-5), 73.93 (-CH-OH), $40.65(\mathrm{C}-\alpha), 31.30(\mathrm{C}-\beta), 21.27\left(-\mathrm{CH}_{3}\right)$; HR ESI-MS $\mathrm{m} / z$ calculated for $\mathrm{C}_{16} \mathrm{H}_{18} \mathrm{O}_{2}[\mathrm{M}-\mathrm{H}]^{-}$241.1234, found $[\mathrm{M}-\mathrm{H}]^{-} 241.1229$.

3-(4-hydroxyphenyl)-1,5-di-(4-methylphenyl)pentane-1,5-dione (7) (Gordonia sp. DSM 44456, $6.9 \mathrm{mg}$, yield $4.9 \%$, Rhodococcus sp. DSM 364, $6.4 \mathrm{mg}$, yield $4.6 \%$ ) creamy powder, mp. $138-140{ }^{\circ} \mathrm{C}$. ${ }^{1} \mathrm{H}$ NMR (600 MHz, Chloroform- $d$ ) $\delta$ (ppm): 7.89-7.84 (m, AA'BB', 4H, H-2', H-6', H-2' $\left.{ }^{\prime}, \mathrm{H}-6^{\prime \prime}\right)$,

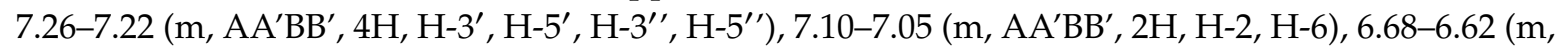
$\left.\mathrm{AA}^{\prime} \mathrm{BB}^{\prime}, 2 \mathrm{H}, \mathrm{H}-3, \mathrm{H}-5\right), 5.57$ (s, 1H, 4-Oㅂ) $), 3.96$ (p, J = 7.1 Hz, 1H, H-3'”), 3.45 (dd, J = 16.2, $6.9 \mathrm{~Hz}$, $2 \mathrm{H}$, one from $\mathrm{H}-2^{\prime \prime \prime}$, one from $\left.\mathrm{H}-4^{\prime \prime \prime}\right), 3.23\left(\mathrm{dd}, J=16.2,7.3 \mathrm{~Hz}, 2 \mathrm{H}\right.$, one from $\mathrm{H}-2^{\prime \prime \prime}$, one from $\left.\mathrm{H}-4^{\prime \prime \prime}\right)$, $2.40\left(\mathrm{~s}, 6 \mathrm{H}, 2 \mathrm{x}-\mathrm{CH}_{3}\right) ;{ }^{13} \mathrm{C}$ NMR (150 MHz, Chloroform- $d$ ) $\delta$ (ppm): $199.04(2 \times \mathrm{C}=\mathrm{O}), 154.58(\mathrm{C}-4)$,

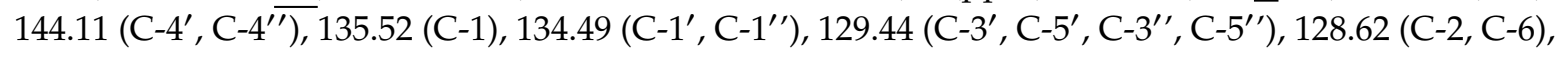
$128.51\left(\mathrm{C}-2^{\prime}, \mathrm{C}-6^{\prime}, \mathrm{C}-2^{\prime \prime}, \mathrm{C}-6^{\prime \prime}\right), 115.62(\mathrm{C}-3, \mathrm{C}-5), 45.40\left(\mathrm{C}-2^{\prime \prime \prime}, \mathrm{C}-4^{\prime \prime \prime}\right), 37.19\left(\mathrm{C}-3^{\prime \prime \prime}\right), 21.81\left(2 \mathrm{x}-\mathrm{CH}_{3}\right)$; HR ESI-MS $m / z$ calculated for $\mathrm{C}_{25} \mathrm{H}_{24} \mathrm{O}_{3}[\mathrm{M}+\mathrm{H}]^{+} 373.1798$, found $[\mathrm{M}+\mathrm{H}]^{+} 373.1800$. 


\section{Conclusions}

The aim of our research was to present the biotransformation of two hydroxychalcones (1 and $\mathbf{4})$ in Gordonia sp. and Rhodococcus sp. cultures. We observed that in both cases, the main and expected product corresponded to dihydrochalcone 2 and $\mathbf{5}$. However, depending on the position of the hydroxyl group, different additional products were isolated.

Biotransformation of 2-hydroxy-4'-methylchalcone proved that the presence of -OH moiety at C-2 position is favorable by monooxygenase, which catalyzed the incorporation at the C-4 position. However, when the hydroxyl group was attached to the C-4, we simultaneously isolated three products; dihydrochalcone 5, alcohol 6 and 1,3,5-triarylpentan-1,5-dione derivative 7. According to our knowledge, our research's novelty provides that among the five biotransformation products, three of them were new and have never been described earlier. The diversity of the obtained biotransformation products may be interesting for a detailed understanding of the enzymes involved in the described transformations of the presented 4'-methylchalcones depending on the location of the hydroxyl moiety in substrates.

Supplementary Materials: The following are available online at http://www.mdpi.com/2073-4344/10/10/1167/s1, Figure S1. ${ }^{1} \mathrm{H}$-NMR $\left(600 \mathrm{MHz}\right.$, Acetone- $d_{6}$ ) spectrum of 2-hydroxy-4'-methylchalcone (1); Figure S2. ${ }^{13} \mathrm{C}$-NMR $\left(150 \mathrm{MHz}\right.$, Acetone- $\left.d_{6}\right)$ spectrum of 2-hydroxy-4'-methylchalcone (1); Figure S3. ${ }^{1} \mathrm{H}-\mathrm{NMR}(600 \mathrm{MHz}$, Chloroform- $d$ ) spectrum of 2-hydroxy-4'-methyldihydrochalcone (2); Figure S4. ${ }^{13} \mathrm{C}-\mathrm{NMR}(150 \mathrm{MHz}$, Chloroform- $d$ ) spectrum of 2-hydroxy-4'-methyldihydrochalcone (2); Figure S5. ${ }^{1} \mathrm{H}-\mathrm{NMR}(600 \mathrm{MHz}$, Chloroform- $d$ ) spectrum of 2,4-dihydroxy-4'-methyldihydrochalcone (3); Figure S6. ${ }^{13} \mathrm{C}-\mathrm{NMR}(150 \mathrm{MHz}$, Chloroform- $d$ ) spectrum of 2,4-dihydroxy-4'-methyldihydrochalcone (3); Figure S7. ${ }^{1} \mathrm{H}-\mathrm{NMR}(600 \mathrm{MHz}$, Acetone- $d_{6}$ ) spectrum of 4-hydroxy-4'-methylchalcone (4); Figure S8. ${ }^{13} \mathrm{C}-\mathrm{NMR}$ (150 MHz, Acetone- $d_{6}$ ) spectrum of 4-hydroxy-4'-methylchalcone (4); Figure S9. ${ }^{1} \mathrm{H}-\mathrm{NMR}(600 \mathrm{MHz}$, Chloroform- $d$ ) spectrum of 4-hydroxy-4'-methyldihydrochalcone (5); Figure S10. ${ }^{13} \mathrm{C}-\mathrm{NMR}(150 \mathrm{MHz}$, Chloroform-d) spectrum of 4-hydroxy-4'-methyldihydrochalcone (5); Figure S11. ${ }^{1} \mathrm{H}-\mathrm{NMR}(600 \mathrm{MHz}$, Chloroform- $d$ ) spectrum of 3-(4-hydroxyphenyl)-1-(4-methylphenyl)propan-1-ol (6); Figure S12. ${ }^{13} \mathrm{C}-\mathrm{NMR}$ (150 MHz, Chloroform-d) spectrum of 3-(4-hydroxyphenyl)-1-(4-methylphenyl)propan-1-ol (6); Figure S13. ${ }^{1} \mathrm{H}-\mathrm{NMR}(600 \mathrm{MHz}$, Chloroform- $d$ ) spectrum of 3-(4-hydroxyphenyl)-1,5-di-(4-methylphenyl) pentane-1,5-dione (7); Figure S14 ${ }^{13} \mathrm{C}$-NMR (150 MHz, Chloroform-d) spectrum of 3-(4-hydroxyphenyl)-1,5-di-(4-methylphenyl) pentane-1,5-dione (7); Figure S15. Chiral HPLC analysis and UV $(\lambda=270 \mathrm{~nm})$ profile of (rac)-3-(4-hydroxyphenyl)-1-(4-methylphenyl)propan-1-ol; Figure S16. Chiral HPLC analysis and UV $(\lambda=270 \mathrm{~nm})$ profile of 3-(4-hydroxyphenyl)-1-(4-methylphenyl)propan-1-ol (6).

Author Contributions: Conceptualization, J.K.; Formal analysis, J.K., B.P.; Investigation, J.K.; Methodology, J.K., B.P.; Supervision, M.A.; Validation, J.K.; Visualization, J.K.; Writing-original draft, J.K.; Writing-review \& editing, J.K., B.P., M.A. All authors have read and agreed to the published version of the manuscript.

Funding: This project was financed by the National Science Centre of Poland, Grant No. 2016/21/B/NZ9/01904.

Conflicts of Interest: The authors declare no conflict of interest.

\section{References}

1. Mai, C.W.; Yaeghoobi, M.; Abd-Rahman, N.; Kang, Y.B.; Pichika, M.R. Chalcones with electron-withdrawing and electron-donating substituents: Anticancer activity against TRAIL resistant cancer cells, structure-activity relationship analysis and regulation of apoptotic proteins. Eur. J. Med. Chem. 2014, 77, 378-387. [CrossRef] [PubMed]

2. Moreira Osório, T.; Delle Monache, F.; Domeneghini Chiaradia, L.; Mascarello, A.; Regina Stumpf, T.; Roberto Zanetti, C.; Bardini Silveira, D.; Regina Monte Barardi, C.; De Fatima Albino Smânia, E.; Viancelli, A.; et al. Antibacterial activity of chalcones, hydrazones and oxadiazoles against methicillin-resistant Staphylococcus aureus. Bioorg. Med. Chem. Lett. 2012, 22, 225-230. [CrossRef] [PubMed]

3. Nowakowska, Z. A review of anti-infective and anti-inflammatory chalcones. Eur. J. Med. Chem. 2007, 42, 125-137. [CrossRef] [PubMed]

4. Singh, P.; Anand, A.; Kumar, V. Recent developments in biological activities of chalcones: A mini review. Eur. J. Med. Chem. 2014, 85, 758-777. [CrossRef] [PubMed] 
5. Panche, A.N.; Diwan, A.D.; Chandra, S.R. Flavonoids: An overview. J. Nutr. Sci. 2016, 5, 1-15. [CrossRef] [PubMed]

6. Sukumaran, S.; Chee, C.; Viswanathan, G.; Buckle, M.; Othman, R.; Rahman, N.A.; Chung, L. Synthesis, Biological Evaluation and Molecular Modelling of 2'-Hydroxychalcones as Acetylcholinesterase Inhibitors. Molecules 2016, 21, 955. [CrossRef]

7. Barreca, D.; Bellocco, E.; Laganà, G.; Ginestra, G.; Bisignano, C. Biochemical and antimicrobial activity of phloretin and its glycosilated derivatives present in apple and kumquat. Food Chem. 2014, 160, 292-297. [CrossRef]

8. Tomas-Barberan, F.A.; Clifford, M.N. Flavanones, chalcones and dihydrochalcones-Nature, occurrence and dietary burden. J. Sci. Food Agric. 2000, 80, 1073-1080. [CrossRef]

9. Mortensen, A. Sweeteners permitted in the European Union: Safety aspects. Scand. J. Food Nutr. 2006, 50, 104-116. [CrossRef]

10. Wang, R.; Huang, L.; Du, Z.; Feng, H. RhCl(CO)(PPh3)2 catalyzed $\alpha$-alkylation of ketones with alcohols. J. Organomet. Chem. 2017, 846, 40-43. [CrossRef]

11. Martinez, R.; Ramon, D.J.; Yus, M. Easy $\alpha$-alkylation of ketones with alcohols through a hydrogen autotransfer process catalyzed by RuCl2(DMSO)4. Tetrahedron 2006, 62, 8988-9001. [CrossRef]

12. Sheldon, R.A.; Woodley, J.M. Role of Biocatalysis in Sustainable Chemistry. Chem. Rev. $2018,118$. [CrossRef] [PubMed]

13. Cao, H.; Chen, X.; Reza Jassbi, A.; Xiao, J. Microbial biotransformation of bioactive flavonoids. Biotechnol. Adv. 2015, 33, 214-223. [CrossRef]

14. Winkler, C.K.; Clay, D.; Van Heerden, E.; Faber, K. Overcoming Co-Product Inhibition in the Nicotinamide Independent Asymmetric Bioreduction of Activated C=C-Bonds Using Flavin-Dependent Ene-Reductases. Biotechnol. Bioeng. 2013, 110, 3085-3092. [CrossRef] [PubMed]

15. Williams, R.E.; Bruce, N.C. "New uses for an Old Enzyme" The Old Yellow Enzyme family of flavoenzymes. Microbiology 2002, 148, 1607-1614. [CrossRef]

16. Filippucci, S.; Tasselli, G.; Labbani, F.K.; Turchetti, B.; Cramarossa, M.R.; Buzzini, P.; Forti, L. Non-Conventional Yeasts as Sources of Ene-Reductases for the Bioreduction of Chalcones. Fermentation 2020, 6, 29. [CrossRef]

17. Scholtissek, A.; Tischler, D.; Westphal, A.; van Berkel, W.; Paul, C.; van Berkel, W. Old Yellow Enzyme-Catalysed Asymmetric Hydrogenation: Linking Family Roots with Improved Catalysis. Catalysts 2017, 7, 130. [CrossRef]

18. Janeczko, T.; Gładkowski, W.; Kostrzewa-Susłow, E. Microbial transformations of chalcones to produce food sweetener derivatives. J. Mol. Catal. B Enzym. 2013, 98, 55-61. [CrossRef]

19. Żyszka-Haberecht, B.; Poliwoda, A.; Lipok, J. Biocatalytic hydrogenation of the $\mathrm{C}=\mathrm{C}$ bond in the enone unit of hydroxylated chalcones-Process arising from cyanobacterial adaptations. Appl. Microbiol. Biotechnol. 2018, 102, 7097-7111. [CrossRef]

20. Kostrzewa-Susłow, E.; Dymarska, M.; Guzik, U.; Wojcieszyńska, D.; Janeczko, T. Stenotrophomonas maltophilia: A gram-negative bacterium useful for transformations of flavanone and chalcone. Molecules 2017, 22, 1830. [CrossRef]

21. Li, Z.; Van Beilen, J.B.; Duetz, W.A.; Schmid, A.; De Raadt, A.; Griengl, H.; Witholt, B. Oxidative biotransformations using oxygenases. Curr. Opin. Chem. Biol. 2002, 6, 136-144. [CrossRef]

22. Kostrzewa-Susłow, E.; Dmochowska-Gładysz, J.; Białońska, A.; Ciunik, Z. Microbial transformations of flavanone by Aspergillus niger and Penicillium chermesinum cultures. J. Mol. Catal. B Enzym. 2008, 52, 34-39. [CrossRef]

23. Roh, C.; Seo, S.H.; Choi, K.Y.; Cha, M.; Pandey, B.P.; Kim, J.H.; Park, J.S.; Kim, D.H.; Chang, I.S.; Kim, B.G. Regioselective hydroxylation of isoflavones by Streptomyces avermitilis MA-4680. J. Biosci. Bioeng. 2009, 108, 41-46. [CrossRef] [PubMed]

24. Schlangen, K.; Miosic, S.; Topuz, F.; Muster, G.; Marosits, T.; Seitz, C.; Halbwirth, H. Chalcone 3-hydroxylation is not a general property of flavonoid 3'-hydroxylase. Plant Sci. 2009, 177, 97-102. [CrossRef]

25. Kozłowska, J.; Potaniec, B.; Żarowska, B.; Anioł, M. Microbial transformations of $4^{\prime}$-methylchalcones as an efficient method of obtaining novel alcohol and dihydrochalcone derivatives with antimicrobial activity. RSC Adv. 2018, 8, 30379-30386. [CrossRef]

26. Amir, M.; Kumar, H.; Khan, S.A. Synthesis and pharmacological evaluation of pyrazoline derivatives as new anti-inflammatory and analgesic agents. Bioorg. Med. Chem. Lett. 2008, 18, 918-922. [CrossRef] 
27. Ohta, H.; Konishi, J.; Tsuchihashi, G. Selective Hydrogenation of Carbon-Carbon Double bonds of Chalcones by Corynebacterium equi IFO 3730. Agric. Biol. Chem. 1985, 49, 665-669. [CrossRef]

28. Shang, X.; Zhou, X.; Zhang, W.; Wan, C.; Chen, J. Tosylhydrazine mediated conjugate reduction and sequential reductive coupling cyclization: Synthesis of 2-arylchromans. Tetrahedron 2015, 71, 8187-8193. [CrossRef]

29. Van Der Geize, R.; Hessels, G.I.; Nienhuis-Kuiper, M.; Dijkhuizen, L. Characterization of a Second Rhodococcus erythropolis SQ1 3-Ketosteroid 9 $\alpha$-Hydroxylase Activity Comprising a Terminal Oxygenase Homologue, KshA2, Active with Oxygenase-Reductase Component KshB. Appl. Environ. Microbiol. 2008, 74, 7197-7203. [CrossRef]

30. Petrusma, M.; Dijkhuizen, L.; Van Der Geize, R. Rhodococcus rhodochrous DSM 43269 3-Ketosteroid $9 \alpha$-Hydroxylase, a Two-Component Iron-Sulfur-Containing Monooxygenase with Subtle Steroid Substrate Specificity. Appl. Environ. Microbiol. 2009, 75, 5300-5307. [CrossRef]

31. Koppolu, S.R.; Balamurugan, R. In situ formed acetals facilitated direct Michael addition of unactivated ketones. New J. Chem. 2017, 41, 1186-1192. [CrossRef]

32. Yanagisawa, A.; Takahashi, H.; Arai, T. One-pot synthesis of 1,5-diketones catalyzed by barium isopropoxide. Tetrahedron 2007, 63, 8581-8585. [CrossRef]

33. Das, G.C.; Hursthouse, M.B.; Malik, K.M.A.; Rahman, M.M.; Rahman, M.T.; Olsson, T. Preparation, spectral studies and X-ray crystal structure of 1,3,5-triphenyl-1,5-pentanedione, C23H2002. J. Chem. Crystallogr. 1994, 24, 511-515. [CrossRef]

34. Paul, N.; Shanmugam, M.J.; Muthusubramanian, S. Facile Microwave-Assisted Michael Addition of Diphenacyl Sulfides to Chalcones Under Solvent-Free Conditions: Generation of Symmetrical and Unsymmetrical 1,5-Diketones. Synth. Commun. 2013, 43, 129-138. [CrossRef]

35. Busch, H.; Hagedoorn, P.; Hanefeld, U. Rhodococcus as a Versatile Biocatalyst in Organic Synthesis. Int. J. Mol. Sci. 2019, 20, 4787. [CrossRef] [PubMed]

36. O'Reilly, E.; Corbett, M.; Hussain, S.; Kelly, P.P.; Richardson, D.; Flitsch, S.L.; Turner, N.J. Substrate promiscuity of cytochrome P450 RhF. Catal. Sci. Technol. 2013, 3, 1490-1492. [CrossRef]

37. Tiwari, U.; Ameta, C.; Rawal, M.K.; Ameta, R.; Punjabi, P.B. MW assisted synthesis of some pyrazoles containing benzotriazole moiety: An environmentally benign approach. Indian J. Chem. Sect. B Org. Med. Chem. 2013, 52B, 432-439. [CrossRef]

38. Bai, X.; Shi, W.Q.; Chen, H.F.; Zhang, P.; Li, Y.; Yin, S.F. Synthesis and antitumor activity of 1-acetyl-3-(4-phenyl)-4,5-dihydro-2-pyrazoline-5-phenylursolate and 4-chalcone ursolate derivatives. Chem. Nat. Compd. 2012, 48, 60-65. [CrossRef] 